\title{
ANALYSIS OF VIRTUAL COMMUNITY MUSIC VIDEO (ACCOUNT (aINDOMUSIKGRAM) ON SOCIAL MEDIA INSTAGRAM
}

\author{
Qilan Umara Ridwan \\ The London School of Public Relations \\ qilannumaraa@gmail.com
}

\begin{abstract}
This Research has the objective to find out how Instagram is used as a media communication platform, for virtual community music video (account @indomusikgram). The research is analysed with cyber community theory under the new media study. The method used is Qualitative Observation, data is obtained by document study. In result, researcher finds out that the community shows instagram is used as a platform as a communication activity within the community with geographical approach, Indonesia and music as symbol and values that unite the community into one ally.
\end{abstract}

Keywords: Social Media, @Indomusikgram, Qualitative

\section{INTRODUCTION}

Social media is a place to socialize with each other. Social media activity is done online on the internet which is not limited by time and space. benefits from social media, among others, as a medium for sales, promotions, foreign affairs and others (Rustian, 2012, March 1).

One of the social media is, Instagram which contains photos, and videos from accounts that have a specific purpose. This is the door for @indomusikgram to take advantage of social media instagram. This Music Video Community account makes their account a place to communicate and share information about music. The activity is to repost or reload recording videos to sing or play an instrument uploaded by an individual on instagram and wants the video to be loaded by @indomusikgram by listing the hashtag \#indomusikgram in caption on the recorded video that is posted on instagramnya (@ indomusikgram,n.d). Account @Indomusic program was born in July 2014 by Christian Bong. the owner of this account is a music lover and wants people to understand the history of music. That's why on several occasions, this account slipped a videovideo that could provoke discussion about music. This music video community account has been flowning to the international world, many of the overseas vlogger musicians who send messages to the @indomusikgram account so that their videos can be loaded. This certainly brings the name of Indonesia to foreign countries, especially in the field of music (hitsss.com, 2017, November 12).

\section{THEORETICAL FRAMEWORK}

New Media The presence of social media is a form of new media, new media has been developed since the 1980s to the present, this becomes a change in the concept of media, where the concept of media is no longer mass but can be a necessity or achievement and a very personal reach, the New Media Concept posits the interaction concept of personal information (Littlejohn \& Foss, 2009, p.143).

New media to be discussed in this research is the media as a communication technology device whose device has characteristics similar to the other and has the character digitisasi for users to communicate (McQuail, 2010, p.148). One of a kind of new media is social media and one of the most famous at the moment is social media Instagram, which became the platform used @indomusikgram Users Instagram increased 1 million in the period of only 12 hours hrata-average 5 million per week (@) mrbambang, 2012, p.15). Instagram is a phone-based application that allows users to upload photos / videos as a form of message delivery to communicate (@ mrbambang, 2012,p.17). 


\section{The Cyber Community}

Cyber Communityis a virtual community communication theory to be a relevant theory in this study as it also deals with virtual communities. Cyber community addresses the cyber world as the "time space" parable suggests that there is a new life in the virtual world (Bungin, 2009, p.296).

Community as place, the meaning of this element is to discuss the cyber space in which the community is built and survives. Example: Geographical location that does not require collective consciousness or occurs by itself for members to become familiar as well as equality and objectivity factors is also identitias, then members become a communion or fellowship (Holmes, 2012, p.360) Community as symbol, is a symbol owned by an interpretable community (Holmes, 2012, p.429). Community as virtual, normanorma, rules and common identity for commitment to keep the community's reputation (Holmes, 2012, p 428). A good virtual community in the perspective of cyber community theory is a community that has the same characteristics of what is mentioned above. The music community@ indomusikgram is a virtual community and cyber community theory is a fitting theory for this research, in order to be able to see the quality and communication activities in virtual community music@ indomusikgram.

\section{METHOD}

In this study is qualitative from the post-postivistic paradigm, finding out the explanation of a phenomenon that occurs. Qualitative is a study that has the belief that true knowledge is knowledge based on facts that surround the subject of research. Facts of fact are obtained through sensing process of observation (Pambayun, 2013, p.5).

Data collection in this research using method of Documentation Technique, where the data obtained in documents that diplubikasi in the form of pictures, writings and events note (Sugiyono, 2013, p. 145). The data obtained from the document study can be seen through the process of observation techniques where the information and data observed by researchers in the process of recall and memory of what is seen, heard and relevant to the research. (Sugiyono, 2013, p.145) In this study, researchers observed the data found in the articles contained about @indomusikgram, data data contained by@indomusikgram and communication process that occurs in @indomusikgram.The main source obtained is from the account @indomusikgram in instagram.

\section{RESULT AND DISCUSSION}

@indomusikgram is an account of interest to music lovers, the birth of the music video community is a new breakthrough for Indonesian homeland, where before the birth of @ indomusikgram, music lovers who want to access online tend to have their own idols or manually search for videos who want watched. Now the musicians are in one container. Content that is reposted daily by @indomusikgram \# is a cover version of a song that has been published publish (For example: Cover Song Titled Terindah - Raisa).

In addition is an account that aims to create a music community, @ indomusikgram also opens up other opportunities that can be a place to improve the career of the musicians themselves. @indomusikgram also opens opportunities for professional cooperation (paid post) for anyone who wants to promote a single or a new album with terms and conditions to be discussed further. The first heard the music. Is feasible (sound or lead instrument is not pitchy bad, and the music accompaniment is also neat or sound clear). @Indomusikgram always give priority to the creator of Indonesian people, but this does not cover the possibility for @indomusikgram repost creator international. (Indomusikgram, 2016, July 30). Account @Indomusikgram was born in July 2014 by Christian Bong.

This account itself is assigned to select who talented talents in Instagram through tags/hashtag \#indomusikgram. Currently, Instagram content from Indomusikgram does not always contain regram / repost from other accounts, but the owner of this account also wants people to understand the history of music. That's why on several occasions, this account slipped in videos that could provoke discussion about music. This music video community account has been flowning to the international world, many 
of the overseas vlogger musicians who send messages to the @indomusikgram account so that their videos can be loaded. This certainly brings the name of Indonesia to foreign countries, especially in the field of music (hitsss.com, 2017, November 12).

@indomusikgram has 688 thousand followers with 4,645 posts from domestic and abroad. However, of course the majority and the top priority are the people of Indonesia. Post from @ indomusikgram is music cover videos of individuals / groups, with the times, just by repost video from someone else's account, it can form a community. Therefore the author will discuss it using cyber community analysis.

\section{Cyber Community Approach}

Community as a place, As a community place built and survives. The type of community, among others, is based on geographical familiarity which does not require a process of consciousness which means that the sacredness occurs by itself, there is also a sense of equality that makes allies (Holmes, 2012, p.360). @Indomusikgram is a community that stands on behalf of Indonesia, by the people of Indonesia and for Indonesia. Thus geographically @ indomusikgram has explored Indonesia as a geographical approach. The familiarity of followers of @indomusikgram that the majority of the people of Indonesia can happen automatically because followers come from the same homeland, speak the same language and tend to have the same way of communication.

Although this community is a community in cyberspace, the familiarity of followers that can be seen from the comment column is maintained. Every time a new video is posted, it's always flooded with comments. Comments are also sometimes a place for discussion. @indomusikgram also tend to create a caption that invites discussion so that followers can express opinions and can discuss in the comment field. While they can only communicate with each other via the comment field, the enthusiasm of the @indomusikgram account followers remains high. In addition to the caption, @Indomusikap jug sometimes loads photos with questions to invite followers to comment and comment. An example of a question loaded by @indomusikgram is "Let's Tell a Song". The most memorable for you! "Which was posted on November 12, 2017. The question was flooded with diverse comments, some just answered the question, some gave the reason why, there was a short story about his life and so on.@Chuaaqila account answered in the comment field with the answer "1st song, "Lagu aku sayang Ibu"(I love mom song)" because it's the first song that I knew when i was small, had once told by parents ". This indicates that followers of @indomusikgram account feel comfortable to express their opinions and tell their story on this community oage.

In accordance with what the inventor and the owner of @Indomusikgram have found, this account also features typical of Indonesia such as videos uploaded on November 10, 2017. Seen someone playing a traditional musical instrument of Indonesia. Then there was a discussion and question about the name of the traditional musical instrument as asked by account @ jorvenys "What is the name of the instrument please tell me I am blind about music hehe" " which is then answered by @ edwardusboy "It is called "sape" from kalimantan". Communication activities between followers from@indomusikgram account looks alive and weighted. Not just sharing but through this community, people can learn about Indonesian Music.This is also an aspect of geographical approach, where the followers majority areIndonesian. In addition, who actively reply in the comments column, also who often like posting from @indomusikgram account have the roles inmaking individuals who are part of the communication activities in this community, as a platform for an ally of music community.

\section{Community as a Symbol}

Like communities in general, the cyber community also has symbols that can be interpreted or interpreted (Holmes, 2012, p.429). From posts made by @ indomusikgram has become a symbol for the community. In addition to this account has written in the biodata column that this account is a "Music Video Community" contents of the Instagram post has become a separate symbol. Posts that contain someone singing, playing music or anything that has a relationship with music. Hence the symbol to be conveyed to audience is the 'Music' itself.

In addition the name of this account is indo-musik-gram where the word Indo is derived from the Indonesian word, then gram from the word Instagram. So it can be concluded that the symbol that wants 
to be given to the public is that this account is a Music account in Instagram coming from Indonesia also contains the music that represents Indonesia.

\section{Community as a virtual}

Common norms, rules and identities directed from commitments or interests among other communities (Holmes, 2012, p 428). Like other Communities, of course @indomusikgram have norms, rules and identity together, it is listed @indomusikgram on biodata on his account in the form of links. Link bit.ly/imgrules is intended for anyone who wants to cooperate with this community. These are guidelines, norms and regulations established by @indomusikgram for the welfare of the community and of course the good name of this community itself.

The link brings anyone who accesses it to the facebook page (indomusikgram, 2016 July 30). @indomusikgram which contains the rules defined. The points among them are: (1) The @indomusikgram account does not accept postings via any channels except the \#indomusikus \#info in Instagram or our curator selections via other sources such as Facebook or YouTube; (2) The daily content of \#indomusikgram is a cover version of a song that has been published publish; (3) Opening opportunities for cooperation in a professional (paid post) for anyone who wants to promote a single or album; (4) Assessing a video is from the clarity of images, audio and creativity; (5) No responsibility for plagiarism, if found plagiarism will be on the blacklist; (6) We support all forms of events or communities and local events; (7) We will always give priority to the creator of the Indonesian people, but remain open with the International creator; (8) No exclusivity to anyone@indomuskgram is serious in making this community, judging by the packaging and production strategies it presents quite clearly for the creators if they want to join. This account is very utilizing the features in Instagram, where all the production is done in social media Instagram. This proves that the community can walk anywhere with members living anywhere.

The presence of new media in the form of social media Instagram, encourages the audience to be creative. Previously they are only audiences of television shows or radio listeners, now they can innovate and become a producer for their own work. This phenomenon is very unique because, someone who previously did not have expertise in the field of technology is now turning technology to develop a career or innovation Such as @indomusikgram which begins with the phenomenon of someone in

love with music, then decided to create a community that also becomes a place for musicians in Indonesia to expand their wings. In the past, musicians struggled to find recording studios or production houses that wanted to buy or produce their music, now they can easily just play guitar at home record it, upload it to social media with \#indomusikgram tags, and get the chance to share their art work to thousands of followers even millions of other public around the world. It certainly is, innovation and phenomena that deserve to be learned and appreciated. Indonesian musicians can now easily reach audiences.

\section{CONCLUSION}

In conclusion@Indomusikgram using social media platform instagram as communication media of music video community as follows, @indomusikgram utilize social media Instagram as a tool to develop its purpose in creating music community from Indonesia. The nature of the communication process in the utilization of social media Instagram is the application of the nature of cyber community.

@Indomusikgram has cyber community properties where the account is a place for its followers and uses Indonesia as a geographical approach which then strengthens the community into an ally. In addition, @indomusikgram uses the symbols of Indonesia, Music and Instagram as symbols of his account where, this symbol describes the music communitywhich is located in Indonesia using Instagram as a communication medium. Having norms and rules for maintaining the identity and existance of the community. The norms and rules applied are also clearly communicated and accessed easily for the musicians who want to be part of this community, for their videos uploaded by @ indomusikgram. Community today that can be glorious in the future even in the virtual world.

\section{REFERENCES}


Bungin. B. (2009). Qualitative Research Analysis. Jakarta: PT. Raja Grafindo Persada.

Hitsss.com. (2017, November 12) Menguni Music Indonesia Through hitts.

Holmes, D. (2012). Communication Theory. Media, Technology and Society. Yogyakarta: Student Literature

Indomusikgram (2016, July 30). Indomusikgram Rules. https://web.facebook.com / notes / indomusikgram / in domusikgra m- rules / 636018743225245?_rdc $=1$ \&_rdr

Littlejohn \& Foss. (2009).Communication Theory. Jakarta: Salemba Humanika

McQuail. D. (2010). Theory of Mass Communication. Jakarta: SalembaHumanika

Pambayun, E. L. (2013). Qualitative Research Methodology in Communication. Jakarta: Publisher Lentera Ilmu Cendekia Rustian S F,(2012, March 1).

What is Social Media. Retrieved from http://www.unpas.ac.id/a pa-it-social-media / Sugiyono (2013October) Quantitative Research Methods, Qualitative and R \& D. Bandung: Alfabeta CV

@Indomusik. (N.d) is obtained from https:/www.instagram.co $\mathrm{m} /$ indomusikgram /? $\mathrm{Hl}=$ en @mrbambang. (2012). Instagram Handbook. Jakarta: PT.Trans Media.

\#ROMOMUSIKGRAM https://www.hitsss.com/m enduniakan-musik-indonesia-via-indomusikgram/ 